\title{
Born to fight? Genetics and combat sports
}

\author{
Emerson FRANCHINI ${ }^{1}$ \\ Combat Sports and Martial Arts Research Group. Physical Education and Sport School. University of \\ São Paulo (Brazil) and Faculty of Sports Sciences, UMR 866. University of Montpellier (France).
}

Recepción: 18/12/2013; Aceptación: 16/01/2014; Publicación: 04/02/2014.

\begin{abstract}
Recently, the influence of genetics on sports performance has received increased attention from many researchers. In combat sports, some investigations have also been conducted. This article's main objective was to review the representation of specific gene polymorphisms in combat sports athletes compared to controls. The following databases were searched: PubMed, Web of Science and SportDiscus. The terms used in this search involved combat sports (boxing, karate, judo, mixed martial arts, taekwondo and wrestling), genes, genetics and candidate genes. Articles published until November 2013 were included if combat sports athletes were considered as a single group (i.e., not mixed with athletes of other sports). Seven studies were found, with two presenting no difference between combat sports athletes and controls, two presenting higher frequencies of candidate genes related to a more endurance-related profile compared to controls, and three where a more power-related gene overrepresentation was found in comparison to controls. Taken together, the initial studies about the genetic characteristics of combat sports athletes are controversial, which is probably due to the mixed (aerobic and anaerobic) characteristic and to the multifactorial performance determinants of these sports.
\end{abstract}

Keywords: Gene; polymorphisms; sports performance.

\section{¿Nacidos para combatir? Genética y deportes de combate}

\section{Resumen}

Recientemente, la influencia de la genética en el rendimiento deportivo ha recibido una creciente atención por parte de muchos investigadores. En deportes de combate también se han desarrollado algunas investigaciones. El objetivo principal de este artículo es revisar la presencia de polimorfismos en genes específicos en deportistas de combate respecto a con grupos de control. Se exploraron las bases de datos: PubMed, Web of Science y SportDiscus. Los términos de búsqueda utilizados fueron combat sports (boxing, karate, judo, mixed martial arts, taekwondo y wrestling), genes, genetics y candidate genes. Se incluyeron artículos publicados hasta noviembre de 2013, si los atletas de deportes de combate eran considerados en un grupo único (i.e., sin mezclarse con atletas de otros deportes). Se encontraron siete estudios, de los cuales dos no presentaron diferencias entre los deportistas de combate y controles, dos presentaron frecuencias más altas de genes candidatos relacionados con un perfil más orientado a la resistencia en comparación con los grupos control, y en tres hubo una mayor representación de genes relacionados con la potencia en comparación con los grupos control. Considerados conjuntamente, los estudios iniciales sobre las características genéticas de los deportistas de combate son controvertidos, lo cual

\section{Nascido para lutar? Genética e esportes de combate}

\section{Resumo}

Recentemente a influência da genética no desempenho esportivo tem recebido aumento de atenção de muitos pesquisadores. Em esportes de combate, algumas investigações também têm sido conduzidas. Esse artigo teve como objetivo principal revisar a representação de polimorfismos genéticos específicos em atletas de esportes de combate em comparação a grupo controle. Os seguintes bancos de dados foram pesquisados: PubMed, Web of Science e SportDiscus. Os termos utilizados nessa busca envolveram combat sports (boxing, karate, judo, mixed martial arts, taekwondo e wrestling), genes, genetics e candidate genes. Artigos publicados até novembro de 2013 foram incluídos se os atletas de esportes de combate foram considerados como grupo único (i.e., não foram agrupados com atletas de outras modalidades). Sete estudos foram encontrados, com dois não apresentando diferença entre os atletas de esportes de combate e controles, dois apresentando maior freqüência dos genes candidatos relacionados a um perfil relacionado ao desempenho aeróbio, e três nos quais maior representação de genes relacionados à potência muscular foram observados nos atletas em relação ao grupo controle. Analisados conjuntamente, os estudos iniciais sobre características genéticas em atletas de esportes de combate são controversos, o que é provavelmente conseqüência da

\footnotetext{
1 E-mail: emersonfranchini@hotmail.com. Dirección: Universidade de São Paulo - USP. Escola de Educação Física e Esporte. Departamento de Esporte. Av. Prof. Mello Morais, 65. Cidade Universitária. 05508-030. São Paulo, Brasil. Http://esportesdecombate.blogspot.com.
} 
probablemente se deba a las características mixtas (aeróbicas y anaeróbicas) y al carácter multifactorial de los determinantes del rendimiento en estos deportes.

Palabras clave: Gen; polimorfismo; rendimiento deportivo. característica mista (aeróbio e anaeróbio) e aos determinantes multifatoriais do desempenho nestas modalidades.

Palavras-chave: Gene; polimorfismo; desempenho

\section{1.- Introduction}

Fighting is one of the world's oldest physical activities practiced by humans. It was conducted for self-defense purposes and to conquer/maintain territory, evolving to fighting rituals in many different places (Moreno, 2011; Moreno, 2013). Specifically, Moreno (2011) demonstrated that almost all hunters-gatherers who belonged to the mitochondrial haplotype L3 had more belligerent culture, including ritualized fights (e.g., wrestling and stick fighting), practices which appear to be independent of the environment - as ritualized fights occur in all climates. Additionally, Moreno suggested that the original human population outside Africa is descended from only two closely related sub-branches that practiced ritual fighting and presenting a higher propensity towards warfare, suicide and the use of assassination to solve conflicts. The ritualized fighting appeared around 80,000 years ago, a period where a change from hunters to warriors took place (Moreno, 2013). Lombardo (2012) recently suggested that sports can be considered a way for men to develop the skills needed in primitive hunting and warfare. Although this author does not mention combat sports as a main sport to develop these skills, it is not totally incorrect to think in these sports as an important contributor to such goal, as hand-to-hand fight is an important part of combat sports, and thus, connected to primitive warfare skills.

Combat sports are practiced worldwide (Kordi, Maffulli, Wroble, \& Wallace, 2009) and have important impact in the medal table of multi-sports events such as the International Olympic Games, where they represent approximately $20-25 \%$ of all medals disputed, and are also disputed professionally in sports such as boxing and mixed martial arts (Franchini, Brito, \& Artioli, 2012). These sport activities can be divided in grappling (e.g., judo, wrestling, Brazilian jiu-jitsu), striking (e.g., boxing, karate, taekwondo) and mixed (e.g., hapkido, jujutsu, mixed martial arts) modalities (Avelar \& Figueiredo, 2009). Each combat sport has its own rules, weight divisions, specific techniques and, consequently, different variables contributing to success. As in many open-skills sports, technique, tactics and physical conditioning are some of the main aspects investigated to increase the understanding of these different contributors to performance and to improve the training prescription to athletes preparing to competition (Smith, 2003). The early identification of children with the proper genetic endowment for some specific sports is expected to be useful for talent selection and development, although many questions involved in such programs remain unanswered (Gonçalves, Rama, \& Figueiredo, 2012).

After the human genome was decoded, some sport scientists started to search for potential genetic factors contributing to high-level physical performance (Ehlert, Simon, \& Moser, 2013). This resulted in the use of the term "candidate genes" (i.e., variations within genes that are not infrequent in the general population, which are compared between one specific athletic group and a similar ethnical control group) or "candidate polymorphisms" to describe the genes probably associated to specific human performance (Lucía, Morán, Zihong, \& Ruiz, 2010). The most extensively studied among the genes investigated are the angiotensin-converting enzyme $(A C E)$, the R577X variant of the actinin- $\alpha 3$ gene (ACTN3) and the peroxisome proliferator-activated receptor $\alpha(P P A R \alpha)$ (Ahmetov et al., 2006; Ehlert, Simon, \& Moser, 2013; Lucía et al., 2010).

The I-allele of the insertion(I)/deletion(D) polymorphism in the ACE gene is overrepresented in elite endurance runners compared with sedentary controls, suggesting that the I-allele is associated with endurance running performance more than the D-allele. This could be attributed to the association between the I-allele and a decreased level of circulating angiotensin II (a vasoconstrictor), reducing the vascular resistance and facilitating the cardiac output during exercise. Additionally, the I-allele seems also to favor muscle efficiency. These two aspects would contribute to improved aerobic performance. On the other hand, the D-allele is related to higher 
angiotensin II circulating levels, which acts as a skeletal-muscle growth factor and, thus, would be associated with performance in strength-oriented performance (Lucía et al, 2010).

Alpha-actinin-3 is a fast-twitch-specific isoform, expressed only in type II myofibers, being important to anchor actin and to regulate coordinated muscle fiber contraction (Kikuchi, Min, Ueda, Igawa, \& Nakazato, 2012). An association between strength and sprint disciplines and the active ACTN3 RR variant as well as an association between endurance-related disciplines and the presence of the null alleles has been observed (Ehlert, Simon, \& Moser, 2013).

The PPAR $\alpha$ is a transcription factor that regulates lipid, glucose, and energy homeostasis, controlling body mass and vascular inflammation. It regulates the expression of genes encoding several key enzymes involved in fat acid oxidation and is considered an important component of the adaptative response to endurance training. Specifically, the intron 7 G-allele is related to endurance performance, while de $\mathrm{C}$-allele is speculated to be more associated to anaerobic performance (Ahmetov et al., 2006).

Although the contribution of specific genes to sports performance in some athletic competitions where very specialized physiological development (e.g., maximal strength, sprint or endurance) seems to be reasonable, its application to more complex sports has received some criticism (Lucía et al., 2010). Despite this criticism, studies of specific polymorphisms have been conducted with combat sports athletes. This review focused on these studies, presenting a critical analysis of the results found by now.

\section{2.- Methods}

The following databases were searched in the beginning of November 2013: PubMed, Web of Science and SportDiscus. The terms used in this search involved combat sports (boxing, karate, judo, mixed martial arts, taekwondo and wrestling), genes, genetics and candidate genes. Onehundred and four articles were retrieved in the original search. Articles were included if combat sports athletes were considered as a single group (i.e., not mixed with athletes of other sports) and if a case-control design was used in the investigation. This approach resulted in a total of seven studies being selected.

\section{3.- Candidate genes and combat sports}

Table 1 presents a synthesis of the studies conducted with athletes from different combat sports and the candidate genes. Figures 1 and 2 present the genotype frequency and the allele frequency, respectively, for the different genes investigated in combat sports athletes.

While combat sports have been classified as mixed in terms of its metabolism predominance, some investigations suggested that striking combat sports such as karate and taekwondo present lower glycolytic reliance, high aerobic contribution and the alactic metabolism contributing to the decisive actions performed by the athletes to score (Beneke, Beyer, Jachner, Erasmus, \& Hütler, 2004; Campos, Bertuzzi, Dourado, Santos, \& Franchini, 2012), while other authors reported data that permit to conclude that grappling combat sports such as Brazilian jiujitsu, judo and wrestling rely more on the glycolytic pathways when compared to striking combat sports (Andreato et al., 2012; Franchini, Artioli, \& Brito, 2013; Yoon, 2002). Additionally, some investigations have presented evidence that athletes with different fighting styles presented different physiological response to the match (Franchini, Takito, \& Bertuzzi, 2005) and different long-term markers of aerobic and anaerobic metabolisms (Gariod, Favre-Juvin, Novel, Reutenauer, Majean, \& Rossi, 1995). Currently it is not possible to determine if the fighting style is determined by the physical fitness or if the physical fitness developed by a given athlete is a consequence of the fighting style adopted. Independently of the interaction effects of fighting style and physical fitness, combat sports athletes have different possibilities to achieve success in their sports. Given these characteristics, the genetic influence on combat sports performance is more difficult to determine than on sports where the physiological characteristics are more closely related to performance determinants. 
Table 1. Combat sports cohorts and the candidate genes.

Sport Sample and control group characteristics*
Gene polymorphism investigated

Results

Author(s)

Ethnic origin: Caucasian. Athletes: 22 Russian boxers (regional or national PPAR intron 7 genotype

Boxing competitive standard). Controls: 1242 healthy unrelated pupils $(\mathrm{n}=534)$ college students $(\mathrm{n}=535)$ and St. Petersburg inhabitants $(\mathrm{n}=173)$ of $P P A R \alpha$ gene $\mathrm{C}$-allele

Ethnic origin: Caucasian. Athletes: 63 Russian wrestlers (regional or PPAR intron 7 genotype

Wrestling national competitive standard). Controls: 1242 healthy unrelated pupils (n distribution and frequencies No difference in the distribution compared to controls = 534), college students $(\mathrm{n}=535)$ and St. Petersburg inhabitants $(\mathrm{n}=173)$ of PPAR $\alpha$ gene C-allele

Ethnic origin: Caucasian. Athletes: 60 Polish combat sport athletes: 19 judo athletes, 22 wrestlers and 19 boxers. Seven highly elite (World or Olympic

Combat Champion), 40 elite (silver or bronze medal winners at World and

sports Olympic competitions or European Champions), 13 sub-elite (participants

in international competitions). Controls: 181 unrelated college sedentary

volunteers

Judo Ethnic origin: Caucasian. Athletes: 28 elite judo athletes from Poland and ACE

Judo Lithuania. Controls: 115 unrelated college student volunteers.

I/D-alleles Higher frequency of insertion in judo athletes compared to Cieszczyk et al. polymorphism controls

ACE I/D and ACTN3 R577X In the ACTN3 genotype distribution, a significant difference polymorphisms frequencies between the international group and controls was observed. Ethnic origin: Japanese. Athletes: 52 international-level wrestlers (World polymorphisms frequencies The ACE genotype distribution and allele frequency of all Championship or Olympic Games participation or Japanese champion) and Wrestling Championship or Olympic Games participation or Japanese champion) and students majoring in physical education

and the association of the wrestlers significantly differed from those of the controls. ACE I/D and ACTN3 R577X Compared with the control group, the odds ratio of the ACTN3
polymorphisms with the polymorphisms with the R-allele + ACE DD genotype being international or national athletic status (international was 3.85 (95\% confidence interval [CI], 2.10-7.03) or 1.37 level vs. national level) (95\% CI, 0.79-2.36), respectively

The frequency of the ACTN3 R-allele was significantly higher in all wrestlers than in controls. ACTN3 XX genotype and X-allele frequency were significantly lower in international-level

Ethnic origin: Japanese. Athletes: 52 international-level wrestlers (24 to eight at World Championships) classified as elite; 28 who participated at

Wrestling World Championship and won the Japanese championship classified as subelite) and 83 national level wrestlers. Controls: 243 (94 male and 149 female)

wrestlers than in controls, but no significant difference was Kikuchi et al.

observed between the national-level wrestlers and the (2013)

controls (trend). The odds ratio of ACTN3 XX genotype frequencies compared with controls was 4.54 for elite, 2.74 for subelite, and 1.08 for national level athletes

Ethnic origin: Hispanic. Athletes: 111 all-time-best Spanish judo athletes,

Judo with international experience and at least one national title. Controls: 343 ethnically matched nonathletic men

Ahmetov et al.

(2006)

eszczyk et al.

Ethnic origin: Caucasian. Athletes: 102 Polish combat athletes (judo, $\mathrm{n}=$ 29; wrestling $\mathrm{n}=35$; boxing $\mathrm{n}=38$ ) and 57 Russian combat athletes

Judo and 29; wrestling, $\mathrm{n}=35$; boxing, $\mathrm{n}=38$ ) and 57 Russian combat athletes

wrestling (boxing, $\mathrm{n}=13$; wrestling, $\mathrm{n}=44$ ). Controls: 342 Polish college students with no competitive sport experience

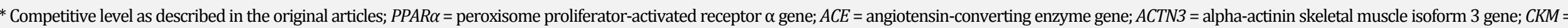
muscle-specific creatine kinase gene; Hardy-Weinberg equilibrium was met in all studies for all groups investigated; judo and wrestling= grappling combat sport; boxing = striking combat sport. 
Figure 1. Genotype frequency (\%) for ACTN3 (Panel A), ACE (Panel B), PPAR- $\alpha$ (Panel C) and CKM (Panel D) genes in combat sport athletes and controls.

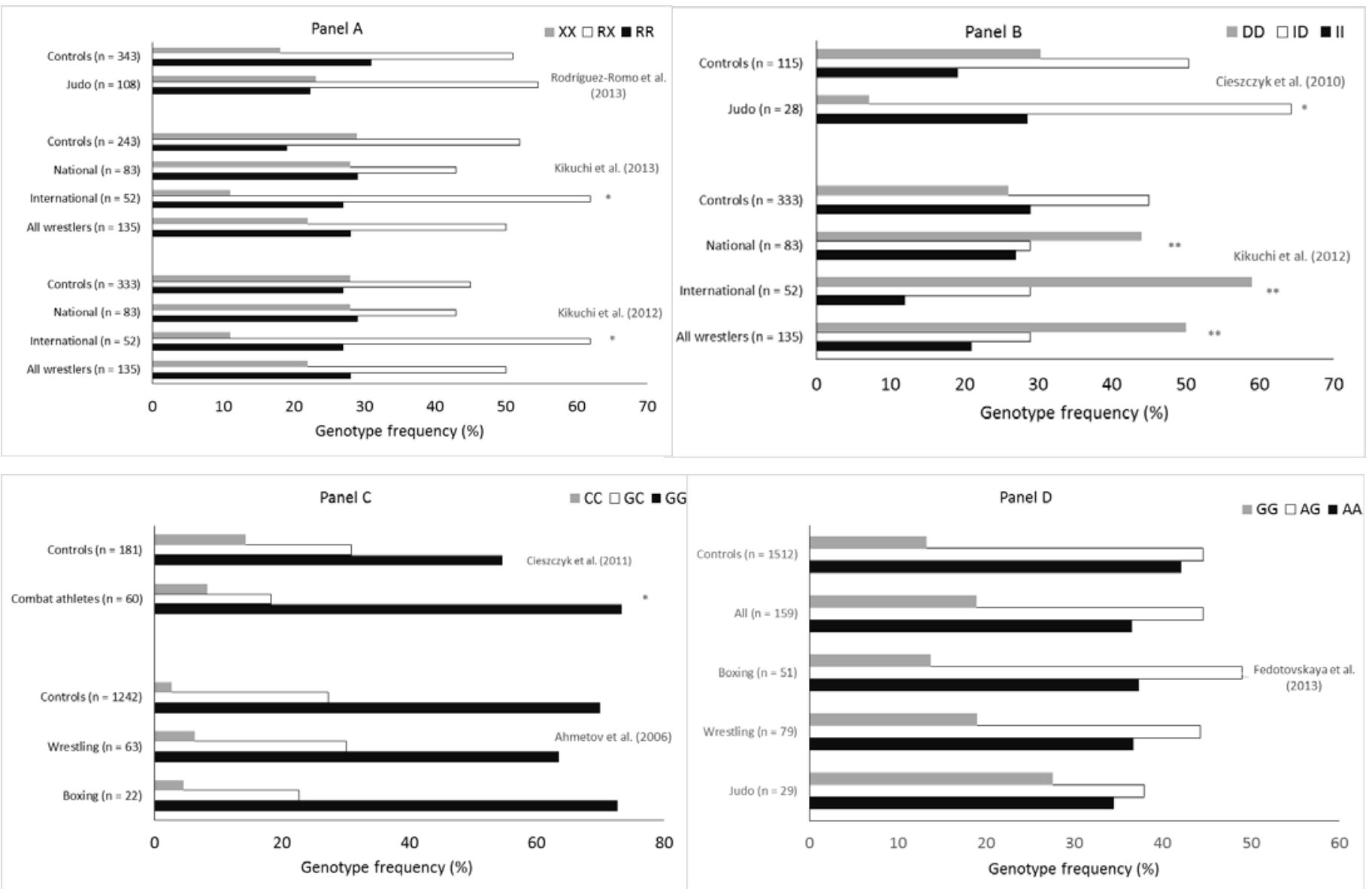

* Different from control distribution $(\mathrm{P}<0.05)$; ** different from control distribution $(\mathrm{P}<0.01)$; letters represent specific genotypes for the genes analysed.

For genotype frequency, the studies presented on Table 1 and Figure 1 reported the following results when combat sports athletes and controls were compared: (1) ACTN3 - two studies found higher frequency in athletes (Kikuchi et al., 2012; Kikuchi et al. 2013) and one did not find any difference (Rodríguez-Romo et al., 2013); (2) ACE - two studies reported different frequency for the athletes (Cieszczyk et al., 2010; Kikuchi et al., 2012); (3) PPAR- $\alpha$ - one observed higher frequency (Cieszczyk et al., 2011), but the other not (Ahmetov et al., 2006); (4) CKM - one study did not find difference (Fedotovskaya et al., 2013).

Concerning allele frequency (Figure 2), from the studies analysed the following results were observed when combat sports athletes and controls were compared: (1) ACTN3 - no difference for the three studies that investigated it (Kikuchi et al., 2012; Kikuchi et al., 2013; Rodríguez-Romo et al., 2013); (2) $A C E$ - two studies reported difference between the athletes and the control groups (Cieszczyk et al., 2010; Kikuchi et al., 2012); (3) PPAR- $\alpha$ - one observed higher frequency (Cieszczyk et al., 2011), but the other did not (Ahmetov et al., 2006); (4) CKM - one found a higher frequency (Fedotovskaya et al., 2013).

To explain the differences in ACTN3 between wrestlers and controls, Kikuchi et al. (2013) suggested that "individuals with the XX genotype, being completely deficient in $\alpha$-actinin-3 protein, would have inferior function of skeletal muscles during the force generation of contraction or a low ability to recover from high-intensity intermittent exercise" (p.60). These factors might determine some aspects of performance in wrestling matches, which could help to explain why the ACTN3 RR allele and the RX genotype would be associated with the level of wrestlers' performance, especially in the international group analyzed by Kikuchi et al. (2012). However, Rodríguez-Romo et al. (2013) did not find any difference for the ACTN3 R577X polymorphism between judo athletes and 
controls and attributed the absence of difference to the fact that judo is more likely a mixed-type sport than a pure power sport. Additionally, Kikuchi et al., (2013) suggested that XX individuals probably would need to have longer recovery time between heavy training sessions, and in case of fatigue, an individually set distribution of training sessions should be organized according to circumstances in order to avoid overtraining or muscle injury.

Figure 2. Allele frequency (\%) for ACTN3 (Panel A), ACE (Panel B), PPAR- $\alpha$ (Panel C) and CKM (Panel D) genes in combat sport athletes and controls.

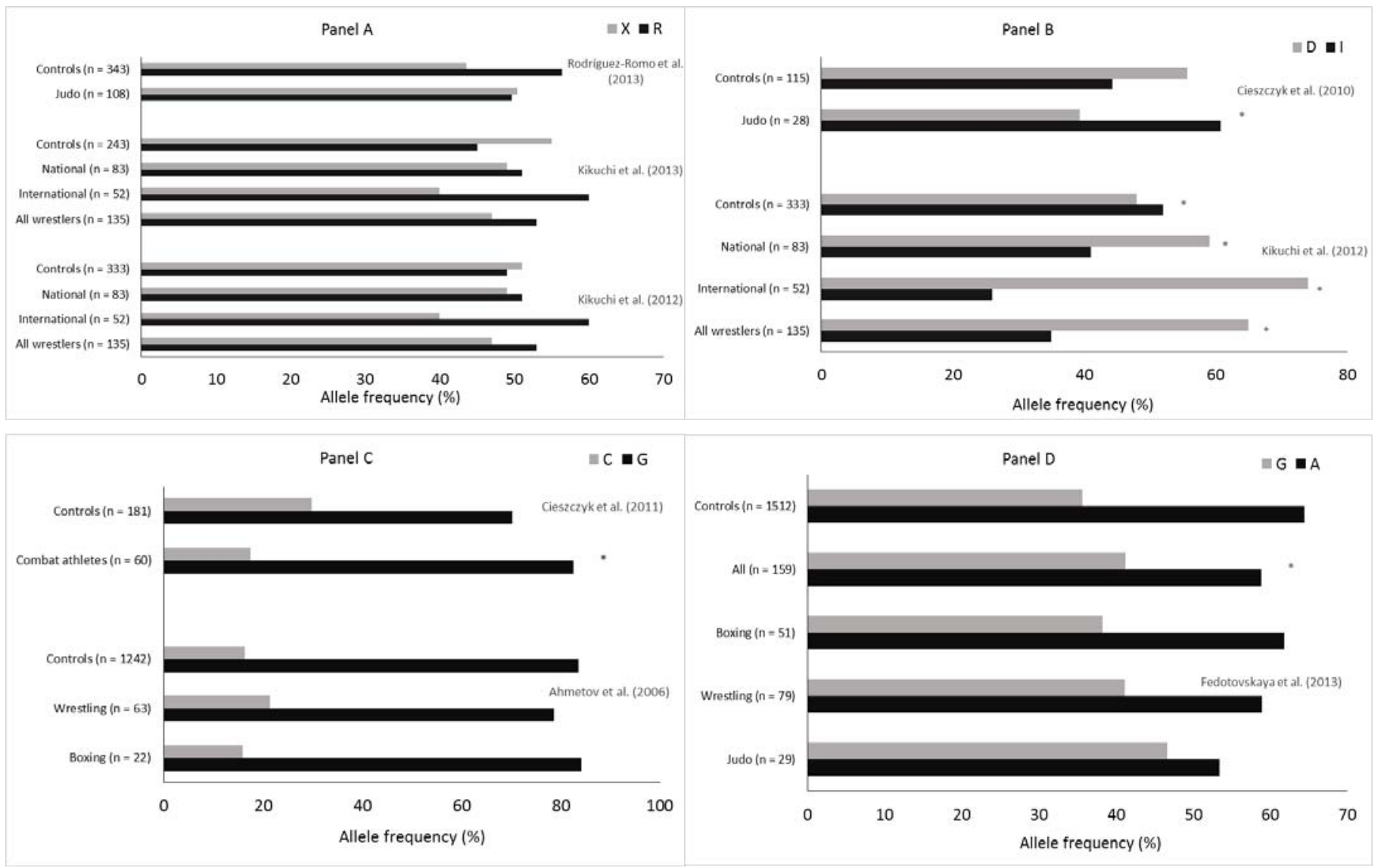

* Different from control distribution $(\mathrm{P}<0.05)$; letters represent specific allele of the genes analyzed.

For the $A C E$, although two studies observed different genotype and allele distributions between athletes and the control groups, one (Cieszczyk et al., 2010) reported a low occurrence of DD genotype and a significant excess of the I allele in judo athletes, while the other (Kikuchi et al., 2012) observed a higher frequency of the DD genotype and an association between the D allele and elite wrestler status. Because judo and wrestling are grappling combat sports with similar metabolic demands (Franchini et al., 2011; Yoon, 2002), the difference observed between these two studies can attributed to the competitive level of the athletes (national level judo athletes and international level wrestlers) or by the training system used in different countries. Probably, training systems focusing on long duration sessions and with high training volumes during the year would benefit athletes with a higher endurance profile than training systems focusing on highintensity power-oriented training sessions, with low volumes during the season.

Concerning the PPAR- $\alpha$, the different results observed by Cieszczyk et al. (2011) and Ahmetov et al. (2006) may be due to the characteristics of the athletes investigated, because Ahmetov et al. (2006) analyzed regional and national level athletes, while Cieszczyk et al. (2011) investigated international level athletes, including Olympic and World Championship medalists. More information about the training and athlete selection systems would provide a better understanding of this difference. 
Fedotovskaya et al. (2013) explained their findings (i.e., higher CKM G allele in combat sports compared to controls) by affirming that power and strength are important determinants of success in combat sports and that this genetic profile would be an advantage for these athletes.

Only one study (Kikuchi et al., 2012) investigated more than one polymorphism in the same sample of combat sports athletes. It found that gene alleles related to muscle power development were overrepresented in a sample of international and national level Japanese wrestlers compared with controls. This investigation reported an association between the $A C E$ D-allele and elite wrestler status and that the ACTN3 RR-allele + RX genotype was associated with athletic performance level in this group, especially with athletes in the international group. A possible explanation given by the authors for this result was that the ACE DD genotype would metabolically induce type IIx fibers, whereas the ACTN3 R-allele would be responsible by the stabilization of these muscle fibers, contributing to the overrepresentation of the ACE DD genotype + ACTN3 Rallele in the international wrestlers group.

Finally, the aspects pointed out by Rodríguez-Romo et al. (2013) should be taken into consideration: (1) "there are indeed numerous other contributors to the complex trait of being an athletic champion that are likely not reducible to defined genetic polymorphisms, included complex gene-gene and gene-environment interaction and interactions between genetic variants that might not influence sports performance individually" (p. 581); (2) "a potential confounder to be kept in mind is that control groups in sports genetics association studies might also include some apparently nonathletic individuals who have a favorable genetic predisposition to sports performance of which they and researchers are unaware." (p. 581).

\section{4.- Final remarks}

The initial studies about the genetic characteristics of combat sports athletes are controversial. These controversial results can be attributed to the mixed (aerobic and anaerobic) metabolic characteristic and to the multifactorial performance determinants of these sports. Despite the suggested difference between grappling and striking combat sports, some authors grouped athletes from these two modalities, which could be considered a non-controlled intervening variable. Future studies should better describe the athletes' competitive level and add some information about the tactical characteristics of them.

\section{Acknowledgments}

The author thanks the Conselho Nacional de Desenvolvimento Científico e Tecnológico CNPq support (236768/2012-3).

\section{References}

Ahmetov, I. I., Mozhayskaya, I. A., Flavell, D. M., Astratenkova, I. V., Komkova, A. I., Lyubaeva, E. V., ... Rogozkin, V. A. (2006). PPAR alpha gene variation and physical performance in Russian athletes. European Journal of Applied Physiology, 97(1), 103-108.

Andreato, L. V., Moraes, S. M. F., Esteves, J. V. C., Pereira, R. R. A., Gomes, T. L. M., Andreato, T. V., Franchini, E. (2012). Physiological responses and rate of perceived exertion in Brazilian jiujitsu athletes. Kinesiology, 44(3), 173-181.

Avelar, B., Figueiredo, A. (2009). La iniciación a los deportes de combate: Interpretación de la estructura del fenómeno lúdico luctatorio. Revista de Artes Marciales Asiáticas, 4(3), 44-57.

Beneke, R., Beyer, T., Jachner, C., Erasmus, J., Hütler, M. (2004). Energetics of karate kumite. European Journal of Applied Physiology, 92(4-5), 518-523.

Campos, F. A. D., Bertuzzi, R., Dourado, A. C., Santos, V. G. F., Franchini, E. (2012). Energy demands in taekwondo athletes during combat simulation. European Journal of Applied Physiology, 112(4), 1221-1228.

Cieszczyk, P., Maciejewska, A., Sawczuk, M., Ficek, K., Eider, J., Jascaniene, N. (2010). The angiotensin converting enzyme gene I/D polymorphism in elite Polish and Lithuaninan judo players. Biology of Sport, 27(2), 119-122. 
Cieszczyk, P., Sawczuk, M., Maciejewska, A., Ficek, K., Eider, J. (2011). Variation in peroxisome proliferator activated receptor $\alpha$ gene in elite combat athletes. European Journal of Sport Science, 11(2), 119-123.

Ehlert, T., Simon, P., Moser, D. A. (2013). Epigenetics in sports. Sports Medicine, 43(2), 93-110.

Fedotovskaya, O., Eider, J., Cieszczyk, P., Ahmetov, I., Moska, W., Sawczyn, S., ... Jascaniene, N. (2013). Association of muscle-specific creatine kinase (CKM) gene polymorphism with combat athlete status in Polish and Russian cohorts. Archives of Budo, 9(3), 233-237.

Franchini, E., Takito, M. Y., Bertuzzi, R. C. M. (2005). Morphological, physiological and technical variables in high-level college judoists. Archives of Budo, 1(1), 1-7.

Franchini, E., Del Vecchio, F.B., Matushigue, K.A., Artioli, G.G. (2011). Physiological profiles of elite judo athletes. Sports Medicine, 41(2), 147-166.

Franchini, E., Brito, C. J., Artioli, G. G. (2012). Weight loss in combat sports: physiological, psychological and performance effects. Journal of the International Society of Sports Nutrition, 9(1), 52.

Franchini, E., Artioli, G. G., Brito, C. J. (2013). Judo combat: time-motion analysis and physiology. International Journal of Performance Analysis in Sport, 13(3), 626-643.

Gariod, L., Favre-Juvin, A., Novel, V., Reutenauer, H., Majean, H., Rossi, A. (1995). Évaluation du profil énergétique des judokas par spectroscopie RMN du P31. Science \& Sports, 10(4), 201-207.

Gonçalves, C. E. B., Rama, L. M. L., Figueiredo, A. B. (2012). Talent identification and specialization in sport: an overview of some unanswered questions. International Journal of Sports Physiology and Performance, 7(4), 390-393.

Kikuchi, N., Min, S. K., Ueda, D., Igawa, S., Nakazato, K. (2012). Higher frequency of the ACTN3 R allele + ACE DD genotype in Japanese elite wrestlers. Journal of Strength and Conditioning Research, 26(12), 3275-3280.

Kikuchi, N., Ueda, D., Min, S. K., Nakazato, K., Igawa, S. (2013). The ACTN3 XX genotype's underrepresentation in Japanese elite wrestlers. International Journal of Sports Physiology and Performance, 8(1), 57-61.

Kordi, R., Maffulli, N., Wroble, R. R., Wallace, A. (2009). Combat sports medicine. London: Springer.

Lombardo, M. P. (2012). On the evolution of sport. Evolutionary Psychology, 10(1), 1-28.

Lucía, A., Morán, M., Zihong, H., Ruiz, J. R. (2010). Elite athletes: are the genes the champions? International Journal of Sports Physiology and Performance, 5(1), 98-102.

Moreno, E. (2011). The society of our "out of Africa" ancestors (I) - the migrant warriors that colonized the world. Communicative \& Integrative Biology, 4(2), 163-170.

Moreno, E. (2013). The "out of Africa tribe" (II) - paleolithic warriors with big canoes and protective weapons. Communicative \& Integrative Biology, 6(3), e24145.

Rodríguez-Romo, G., Yvert, T., Diego, A., Santiago, C., Durana, A. L. D. Carratalá, V., ... Lucia, A. (2013). No association between ACTN3 R577X polymprphism and elite judo athletic status. International Journal of Sports Physiology and Performance, 8(5), 579-581.

Smith, D. J. (2003). A framework for understanding the training process leading to elite performance. Sports Medicine, 33(15), 1103-1126.

Yoon, J (2002). Physiological profiles of elite senior wrestlers. Sports Medicine, 32(4), 225-233.

\section{Author's biographical data}

Emerson Franchini is an Associate Professor at School of Physical Education and Sport, University of São Paulo, Brazil, where he is the coordinator of the Martial Arts and Combat Sports Research Group. He has investigated martial arts and combat sports for 18 years and has published papers, chapters and books about different aspects of these activities. He has experience with physical preparation of international level judo athletes (World Championship and Olympic medal winners) and is a $2^{\text {nd }}$ dan black belt in judo since 2002 . Email: emersonfranchini@hotmail.com. 